\title{
FOCUS teszt: új, számítógép-alapú vizsgálati eszköz 3-8 éves gyermekek számára
}

\section{Józsa Krisztián - Barrett C. Karen - Józsa Gabriella - Morgan}

\section{A. GEORGE}

Szegedi Tudományegyetem Neveléstudományi Intézet és Kaposvári Egyetem Neveléstudományi Intézet - Colorado State University, Human Development and Family Studies - Debreceni Tudományegyetem, HTDI Neveléstudományi Doktori Program - Colorado State University, School of Education

\begin{abstract}
A tanulmány a FOCUS (Finding Out Children's Unique Strengths) tesztet ismerteti. A számítógép-alapú új méröeszköz 3-8 éves kor között vizsgálja az elsajátitási motivációt, a végrehajtó funkciót, valamint a betü- és számismeretet. Ezek fontos komponensei az alapvetö tanulási lépcsőknek (ATL). E tényezőknek jelentős szerepe van az iskolai tanulás sikerességében. A tanulmány bemutatja a FOCUS teszt kidolgozásának az elméleti hátterét, a méröeszköz felépitését, szubtesztjeit. Beszámol az első próbamérés tapasztalatairól. Ennek során 12 óvodás gyermek egyéni verbális vizsgálatával került sor a feladatok kipróbálására. A második próbamérésben már a számitógép-alapú változatot alkalmaztuk, a mintát 3-8 éves gyermekek alkották, összesen 247 fó. Az új méröeszköz megfelelö reliabilitásúnak és validitásúnak bizonyult. Az online változatot követöen elkészült az offline mobil applikáció is. A webalapú méröeszköz és az applikáció angol és magyar nyelven érhetö el. A tanulmány zárása röviden kitér a teszt további fejlesztésére, a tervezett kutatási felhasználásra.
\end{abstract}

Kulcsszavak: FOCUS, alapvetö tanulási lépcsők, elsajátitási motiváció, végrehajtó funkció, számitógép-alapú értékelés

\section{Bevezetés}

Számos hazai és nemzetközi vizsgálat foglalkozik az iskolai sikerességet befolyásoló tényezőkkel (például, Burchinal, Magnuson, Powell \& Hong, 2015; Józsa \& Barrett, 2018; Snow, 2006). Jól ismert, hogy az iskolai tanulás elöfeltételét jelentő készségek - mint például a DIFER készségek (Józsa, 2016; Nagy, Józsa, Vidákovich és Fazekasné, 2004) - meghatározóak a későbbi iskolai tanulás sikerességében. Az újabb kutatások arra is rávilágítanak, hogy a tanulás előfeltétel-készségei mellett az elsajátítási motivációnak és a végrehajtó funkciónak is fontos szerepe van az iskolai teljesítményben. E tényezők erősebb prediktív erővel bírnak az iskolai sikerességre, mint az intelligencia (Józsa, 2007; Józsa \& Barrett, 2018; Zelazo, Blair \& Willoughby, 2016). Az elsajátítási motiváció és a végrehajtó funkció az úgynevezett alapvető tanulási lépcsők (ATL) fö összetevői. E személyiségtényezők kiemelten fontosak a gyermeki fejlődésben, ennek ellenére nem is- merünk a szakirodalomban olyan vizsgálati eszközt, amely alkalmas lenne számítógép-alapú mérésükre óvodás és kisiskolás korban. Ebből kiindulva egy új mérőeszköz kidolgozását kezdtük meg (Barrett, Józsa \& Morgan, 2017; Józsa, Barrett \& Morgan, 2017). Jelen tanulmányunkban ennek a mérőeszköznek az elméleti hátterét és főbb jellemzőit ismertetjük. A FOCUS (Finding Out Children's Unique Strengths) elnevezésű teszt játékos feladatokkal méri a gyermekek elsajátítási motivációját, végrehajtó funkcióját, valamint szám- és betűismeretét 3-8 éves kor között.

\section{Alapvető tanulási lépcsők}

Az alapvető tanulási lépcsők (ATL) kifejezést az Approaches to Learning (ATL) magyar fordításaként használjuk. Fordításunk szóhasználatát - a tartalom visszaadása mellett - az is befolyásolta, hogy a magyar mozaikszó így azonos az eredeti angollal. Az ATL egy átfogó fogalom, mely a tanulással kapcsolatos készsé- 
geket, képességeket, valamint a tanulás iránti lelkesedést és elkötelezettséget foglalja magában (Hayson, 2008). Az ATL fontos összetevője a kitartás, az érdeklődés, a tervezés, a motiváció (Bustamante, White \& Greenfield, 2017), a flexibilitás, figyelem, szervezés, szabálykövetés (Razza, Martin E Brooks-Gunn, 2015), az önszabályozás, felelősségvállalás, együttműködés (McClelland, Acock \& Morrison, 2006).

Az egyes szerzők az ATL-nek különböző komponenseit emelik ki. Egyetértés van azonban közöttük abban, hogy a kognitív és az affektív összetevőket egyaránt hangsúlyosnak tekintik. Az ATL-lel azonos fogalmat takar a SAL (Student's Approaches to Learning) rövidítés is (Janero, Duarte, Araújo E Gomes, 2017).

Az ATL értelmezése egybecseng azzal a megközelítéssel, ahogyan a hazai szakirodalomban Nagy József $(2000,2010)$ a kompetencia fogalmát meghatározza. Nagy definíciójában a kompetencia fö összetevői a készségek és a motívumok. E szerint egy feladat sikeres végrehajtásához rendelkezni kell a szükséges készségekkel, emellett kellően motiváltnak kell lenni. Ha bármelyik összetevő hiányzik, nem rendelkezik az egyén fejlett, hatékony kompetenciával az adott területen.

Az amerikai National Education Goals Panel (1997) szerint az ATL az iskolaérettség kulcsfontosságú dimenziója. Több kutatás bizonyította, hogy az ATL összetevői, azok fejlettségi szintjei jelentős szerepet játszanak a gyermekek iskolaérettségében, iskolai teljesítményében (Blair E Razza, 2007; McClelland et al., 2007; Mischel, Shoda E Rodriguez, 1989; Zelazo, Blair $\mathcal{E}$ Willoughby, 2016). Az óvodáskori ATL előre jelzi az iskolai sikerességet az olvasás és matematika területén (McClelland, Acock E Morrison, 2006; Morgan, Farkas \& Wu, 2011).

Tanulmányunkban az ATL-nek két alapvető komponensét emeljük ki: az elsajátítási motivációt és a végrehajtó funkciót, ezeket a következő két fejezetben mutatjuk be. Az elsajátítási motivációnak és a végrehajtó funkciónak is több olyan összetevője van, amit az ATL-lel foglalkozó szerzők - fontosságuk alapján - külön-külön is kiemelnek. A FOCUS tesztben erre a két ATL komponensre készítettünk feladatokat.

\section{Elsajátítási motiváció}

Az előző fejezetben az elsajátítási motivációt (mastery motivation) mint az ATL egyik kulcsfontosságú összetevőjét határoztuk meg. Morgan, Harmon és Maslin-Cole (1990) szerint az elsajátítási motiváció egy többdimenziós, intrinzik eredetű pszichológiai mozgató erő, amely arra sarkallja az egyént, hogy megpróbáljon elsajátítani egy olyan készséget, megoldani egy olyan feladatot, ami legalább mérsékelt kihívást jelent a számára. Az elsajátítási motiváció két fő összetevőből áll: az instrumentális komponensből, amely a kihívást jelentő feladatokban, helyzetekben mutatott kitartásban jelenik meg; valamint az expresszív komponensből, amely a kihívásra adott pozitív és negatív érzelmi reakciókban nyilvánul meg. Az elsajátítási motiváció különböző területeken nyilvánulhat meg, ennek megfelelően megkülönböztetünk kognitív (értelmi), szociális (társas) és motoros (mozgásos) elsajátítási motivációt (Barrett E Morgan, 2018; Morgan, Józsa E Liao, 2017).

Az elsajátítási motiváció jobb prediktív erővel bír a gyermekek kognitív képességének fejlődésében, mint az intelligencia, döntő szerepet játszik az iskolai teljesítményben (Gilmore, Cuskelly \& Purdie, 2003, Józsa E Barrett, 2018; Mercader, Presentación, Siegenthaler, Moliner \& Miranda, 2017).

\section{Végrehajtó funkció}

A végrehajtó funkció (executive function) ugyancsak fontos komponense az ATL-nek. A fogalom olyan komplex kognitív folyamatokra utal, amelyek részt vesznek a gondolatok, az érzelmek és a viselkedés tudatos irányításában, szabályozásában (Diamond, 2013; D. Molnár, 2017; Garon, 2016). Általános egyetértés mutatkozik abban, hogy a végrehajtó funkciónak három komponense van: a munkamemória, a gátlás és a kognitív flexibilitás (Blair E Diamond, 2008; Tsermentseli \& Poland, 2016). A végrehajtó funkció fogalmát, legfontosabb vizsgálati eszközeit Józsa és Józsa (2018) tanulmánya mutatja be magyarul. 
Focus teszt: új, számítógép-alapú vizsgálati eszköz 3-8 éves gyermekek számára

Több vizsgálat is igazolta, hogy a végrehajtó funkció összetevői központi szerepet játszanak az iskolaérettségben és az iskolai teljesítmény sikerességében (Blair, 2002; Normandeau \& Guay, 1998). A koragyermekkorban végzett végrehajtó funkció mérések azt mutatják, hogy a végrehajtó funkció komponenseknek jelentős előrejelző ereje van a sikeres óvoda-iskola átmenetben (Blair E Razza, 2007), az iskolai teljesítményben és a szociális kompetencia fejlettségében (Mischel, Shoda E Rodriguez, 1989). A végrehajtó funkció ezekben a vizsgált változókban nagyobb prediktív erővel bír, mint az IQ (Zelazo, Blair E Willoughby, 2016).

Az ezredfordulóig a végrehajtó funkciót tisztán kognitív megközelítésben vizsgálták, figyelmen kívül hagyták az érzelmek és a motiváció szerepét (Peterson $\mathcal{E}$ Welsh, 2014). Az elmúlt évtized során azonban egyre inkább megnőtt az érdeklődés az affektív tényezők szerepe iránt a végrehajtó funkció működésében (Józsa és Józsa, 2017). A tisztán kognitív nézőponttól való elmozdulásban jelentős szerepe volt Zelazo és Müller (2002) munkájának, akik rámutattak a hideg és meleg végrehajtó funkció közötti különbségekre. A hideg és a meleg végrehajtó funkciót az különbözteti meg, hogy milyen mértékű érzelmi telítettség, motiváltság kapcsolódik az egyén számára az adott feladathoz.

\section{Egyéni verbális vizsgálat}

Az ATL fent említett összetevőinek a mérésére egy számítógépes vizsgálati eljárást terveztünk. A számítógépes program fejlesztése előtt egyéni verbális vizsgálat formájában próbáltuk ki a feladatokat (Józsa, Barrett, Józsa, Kis E Morgan, 2017). Egyéni verbális vizsgálatnak nevezzük azt az adatgyüjtési módot, amikor a vizsgálatban egyetlen gyermek vesz részt, a kérdező egyéni feladathelyzetben, előre megadott mérési protokoll szerint jár el. Ezt a pedagógiai laboratóriumi módszerek közé tartozó eljárást szemtől-szembe (face-to-face) adatgyüjtésnek is nevezik (Gliner, Morgan $\mathcal{E}$ Leech, 2017). Ilyen vizsgálati eszköz például a fentebb már hivatkozott DIFER is.
A vizsgálattal az volt a célunk, hogy lássuk, értik-e a gyermekek a feladatokat, tetszik-e nekik, megfelelően definiáltuk-e a nehézségi szinteket. Az adatfelvételre egy kecskeméti óvoda erre alkalmas szobájában került sor. A mérés során a gyermekek komfortérzetét a jelen lévő óvónő biztosította. A próbamérésben 12 fő 4-7 éves óvodás vett részt.

\section{A próbamérés méröeszköze}

A FOCUS-ban szereplő elsajátítási motivációt mérő két szubtesztet Morgan, BuschRossnagel, Maslin-Cole és Harmon (1992) által kidolgozott modell alapján hoztuk létre. Ennek a mérési modellnek az a lényege, hogy egy feladattípusnak fokozatosan nehezedő variánsai vannak. Ezek közül adaptív módon azt a nehézségi szintet választjuk ki a gyermeknek, ami optimális mértékű kihívást jelen számára.

A betü- és számfelismerő feladatok mindegyike nyolc nehézségi szintet tartalmazott. A különböző nehézségi szintekhez tartozó feladatokat külön-külön színes A/4-es lapra nyomtattuk ki. A papíron a feladatok elhelyezkedése és a nehézségi szintek elrendezése megegyezett a számítógépre tervezett feladatokéval, tehát a gyermekek egy-egy monitorkép jellegű elrendezést láttak maguk előtt az asztalon. A feladatvégzéshez korongokat kaptak, ezeket kellett rátenniük a megtalált betűkre, számokra. Az óvodásoknak az eléjük tett papírról azt a betüt vagy számot kellett kiválasztani, amit a célkártya mutatott.

A végrehajtó funkció mérésére a Milnerféle (1963) Wisconsin Kártyaszortírozó Teszt Zelazo, Müller, Frye és Marcovitch (2003) által kidolgozott változatát adaptáltuk. A szortírozáshoz piros, zöld, sárga és kék színű kicsi és nagyméretű virágot, nyuszit, hajót és repülőt ábrázoló nyomtatott képeket használtunk. A papíralapú mérés hat nehézségi szintet tartalmazott, például: szortírozás méret, alak és szín szerint, illetve szortírozás fordított szín, fordított alak és fordított méret szerint. A feladatok megoldása során fontos szerepe volt a váltásnak az egyik feladattípusról (utasításról) a másikra. A feladathoz A/4-es lapra nyomtattuk ki a megfelelő formával ellátott kosa- 
rakat, amelyekre az előre legyártott, laminált képeket kellett a gyermekeknek az utasításnak megfelelően rárakni.

\section{Az egyéni verbális vizsgálat lebonyolitása}

A mérést két adatfelvevő végezte együtt, amíg az egyik a gyermekkel foglalkozott, adta neki az instrukciókat, addig a másik mérte az időt és vezette a méréshez kidolgozott adatrögzítő lapot. Rögzítésre került a feladatmegoldáshoz szükséges idő, a hibás és a hiányzó képek száma. A betű- és számkereső feladatban hibásnak tekintettük a választ, ha a gyermek olyan képre tette a korongot, ami nem egyezett a célképen szereplővel. Hiányzónak tekintettük a választ, ha a gyermek nem tett korongot olyan képre, ami megegyezett a célképen szereplővel, azaz amire kellett volna. Emellett szövegesen feljegyeztük az érzelmi reakciókat, a feladat feladására irányuló jeleket, a nem feladatorientált tevékenységet. Az adatfelvételt a gyermekek felénél a betűkereső játékkal kezdtünk, a másik felénél a számkereső játékot vettük előre, majd utána következett a kártyaszortírozó és memóriajáték. A betűés a számkereső, illetve a kártyaszortírozó és memóriajáték mérésére két külön napon került sor. Minden gyermek megoldotta mind a nyolc számkereső, és mind a nyolc betűkereső szintet, valamint mindegyik végrehajtó funkció és memóriajáték feladatot is. Ezzel ellenőriztük empirikusan a feladatok elméletileg feltételezett nehézségi sorrendjét.

A vizsgálat megkezdésekor próbafeladatot adtunk a gyermekeknek. A próbafeladat célja az volt, hogy ellenőrizzük, hogy a gyermekek értik-e az utasításokat. A próbafeladatnál szükség esetén az instrukció elmagyarázásával segítettük a feladat megértését. Részletesebb segítségre egy gyermek esetében volt szükség. A próbafeladat megoldása után minden gyermek értette az utasítást.

Fentebb említettük, hogy egy óvodás nem tudott hozzákezdeni a feladathoz, mert nem értette az utasítást. Másodszori magyarázat után azonban neki sem okozott gondot a feladatok megoldása. E tapasztalat alapján a próbafeladatban lecseréltük a betűket és a számokat figurákra (házikó, hajó, banán), hogy a gyermekek számára ismertebb rajzokon történjen a begyakorlás, az utasítás megértése. A számítógépes változatba beépítettük azt a funkciót, hogy a program addig nem engedi tovább a gyermeket a gyakorló szintről, amíg nem érti az utasítást. Ebből a célból, ha szükséges, több próbafeladatot is kap a gyermek az instrukció megértése céljából. Ha többszöri nekifutásra sem megy a gyermeknek a próbafeladat megoldása, akkor nem indul el a számítógépes mérés.

A betü- és számkereső feladatok első két szintje minden gyermek számára könnyünek bizonyult, megtaláltak minden betűt, számot ezeken a szinteken. A szintek nehezedésével nőtt a gyermekek feladatmegoldáshoz szükséges ideje. A magasabb szinteken többet hibáztak, emellett több volt a hiányzó (nem megtalált) kép is. Néhány gyermek esetében a magasabb szinteknél láthatóan kisebb volt a kitartás, megfigyelhető volt a nem feladatorientált viselkedés. Két gyermek a betükereső utolsó két szintjéhez hozzá sem kezdett.

A próbamérés után néhol változtattunk a betűk és számok összetételén. Ezt azért láttuk szükségesnek, hogy a nagyobb gyermekek között a nehezebb feladatok jobban differenciáljanak. Pl. az YZ betűkombinációt VW-re változtattuk, és olyan betűkombinációk közé tettük, amik vizuálisan is hasonlóak hozzá (pl. MW).

A kártyaszortírozó játéknál a gyermekeknek aszerint kellett a korsarakra tenni a képeket, amilyen utasítást adott neki a mérésvezető. A játékot ebben az esetben is egy próbafeladattal kezdtük. Itt segítséget, visszajelzést kapott a gyermek, magyarázattal javítottuk a rossz válaszát. Ennél a feladatnál az számított hibának, ha a gyermek nem a megfelelő kosárba tette a képet. Az éles feladatok esetében azonban sem a betű- és számkeresőnél, sem a kártyaszortírozónál nem adtunk visszajelzést a gyermekeknek sem a jó, sem a rossz válaszok esetében.

Az egyéni verbális vizsgálat tapasztalatai alapján a szám- és betűkereső játék nyolc nehézségi szintjéből minden gyermek négyetnégyet kap a számítógépes mérés során. Egy 
Focus teszt: új, számítógép-alapú vizsgálati eszköz 3-8 éves gyermekek számára

olyat, amit az életkora alapján könnyűnek vélünk, két közepes nehézségüt és egy nehezet. Így a számítógépes változatba a $2 \times 8$ szint helyett $2 \times 4$ életkor szerinti nehézségi szint kap helyet. A végrehajtó funkció és a memóriajáték esetében pedig a $2 \times 8$ szintből három-három feladat: egy feltételezetten könnyü, egy közepesen nehéz és egy nehéz.

Az egyéni verbális vizsgálattal szerettük volna felmérni a feladat előtti, közbeni és utáni érzelmi reakciókat is. Ehhez a gyermek önértékelését használtuk. Négy érzelmet (boldog, közömbös, szomorú, mérges) ábrázoló smiley képeket tettünk minden gyermek elé, és azt kértük, hogy mutassanak rá arra a képre, ahogyan éppen érzik magukat. A válaszok azonban nem tükrözték megbízhatóan a gyermekek viselkedésében megnyilvánuló érzelmi reakciókat. Leginkább a boldog arcot választották, mert az tetszett nekik. Egy-két gyermek nem a feladathoz kapcsolódó érzelmi állapotról beszélt, hanem például arról, ami éppen az óvodában történt vele aznap reggel. A mérés tapasztalatai alapján arra következtettünk, hogy ebben az életkorban még nem tudnak a gyermekek ilyen önértékelést adni, ezért a számítógépes mérésből ezt a részt kihagytuk.

Azt tapasztaltuk, hogy minden óvodás örömmel vett részt a próbamérésben. Játéknak tekintették, tetszett nekik a betűkkel, számokkal, figurákkal való foglalkozás. A próbamérés során szerzett tapasztalatok és apróbb módosítások után alkalmasnak tartottuk a feladatokat arra, hogy megkezdjük a számítógépes szoftver kidolgozását (Józsa, Barrett, Józsa, Kis E Morgan, 2017).

\section{A FOCUS teszt felépítése}

Az egyéni verbális vizsgálat során szerzett tapasztalataink felhasználásával kezdtük meg a mérési modellünk számítógépes adaptációját. A számítógép-alapú mérőeszközt 3-8 éves gyermekek számára készítettük online, webalapú változatban. A tesztet érintőképernyős tableten, valamint asztali számítógépen egér segítségével is meg lehet oldani. Óvodás gyermekek esetében egyéni vizsgálattal, iskolás korban pedig már csoportosan, fülhallgató használatával is megvalósítható az adatfelvétel (lásd 1. ábra). A program összesen hat játékot tartalmaz: a 1) betüfelismerés, és a 2) számfelismerés feladatok az iskolai tanulás előfeltétel-készségeit mérik. A 3) betűkeresés és a 4) számkeresés az elsajátítási motiváció egyik fontos aspektusát, a feladatorientált kitartást vizsgálja, vagyis azt, hogy egy kihívást jelentő feladat megoldásában mennyire kitartó a gyermek. A 5) memóriajáték a munkamemóriát méri azzal, hogy a gyermeknek meg kell jegyeznie a kártyák elhelyezkedését ahhoz, hogy megtalálja a párokat; a gátlás mérésére a következő szinten az előző játékban elhelyezkedő kártyák elnyomása szolgál. A 6) kártyaszortírozó feladat a munkamemóriát a szortírozás szabályának fejben tartásával; a gátlást az új szabály megjelenésekor az előző szabály elnyomásával; és a kognitív flexibilitást a szabályok közötti váltással vizsgálja. A kártyaszortírozó feladat tehát a végrehajtó funkció mindhárom komponensét egyidejűleg, komplex módon vizsgálja. A program öt korcsoportot különböztet meg: 1) 4 év alattiak, 2) 4-5 évesek, 3) 5-6 évesek, 4) 6-7 évesek és 5) 7 év fölöttiek. Az öt korcsoport eltérő nehézségű feladatokat kap. A narrátor Kismackó, aki ismerteti a feladatokat, szükség esetén többször elmondja az utasítást, adott esetben javasolja, hogy a gyermek kérjen segítséget a jelen lévő mérőbiztostól (pedagógustól), ha nem értette meg a feladatot. 


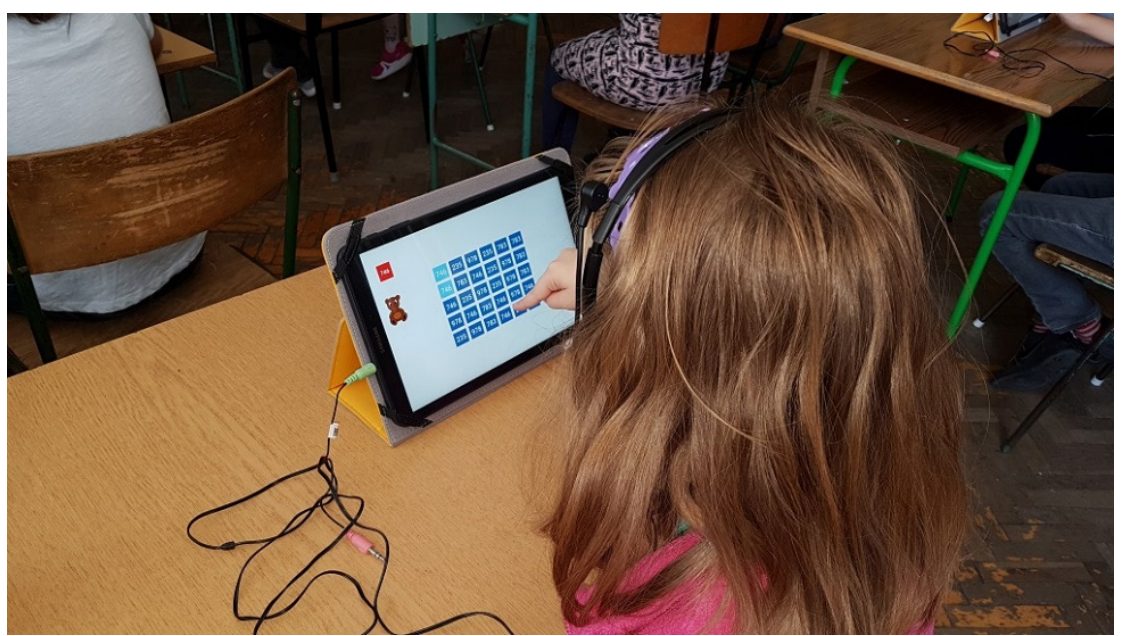

1. ábra: A FOCUS teszt csoportos adatfelvétele során készült osztálytermi fénykép

Az adatfelvétel két külön mérési alkalommal történik. Az első időpontban a betü- és számismerethez, valamint az elsajátítási motivációhoz kapcsolódó feladatok (1-4. feladat), a másik időpontban a végrehajtó funkcióhoz kapcsolódó feladatok (5-6. feladat) kerülnek sorra. Mindkét mérési alkalom hozzávetőlegesen 15-20 percet vesz igénybe.

\section{A program részei}

A teszt egy képfelismerő játékkal indul, ahol a gyermeknek különböző figurákból (hal, madár, nyuszi, cica, egér) kell kiválasztania a Kis- mackó által megnevezett állat képét (2. ábra). A játékot a program szükség esetén többször is megismétli, mindaddig, amíg a gyermek biztonsággal érti az utasítást, s a megfelelő figura kiválasztásával válaszolni tud. Ha a gyermek többszöri próbálkozás után is sikertelen ebben a próbafeladatban, akkor nem kap további feladatokat és kedvesen elköszön tőle Kismackó. A próbamérések tapasztalatai alapján 1\% alatti azon óvodás gyermekek száma, akik nem értették meg a próbafeladatot, ezáltal nem vettek részt a további adatfelvételben.
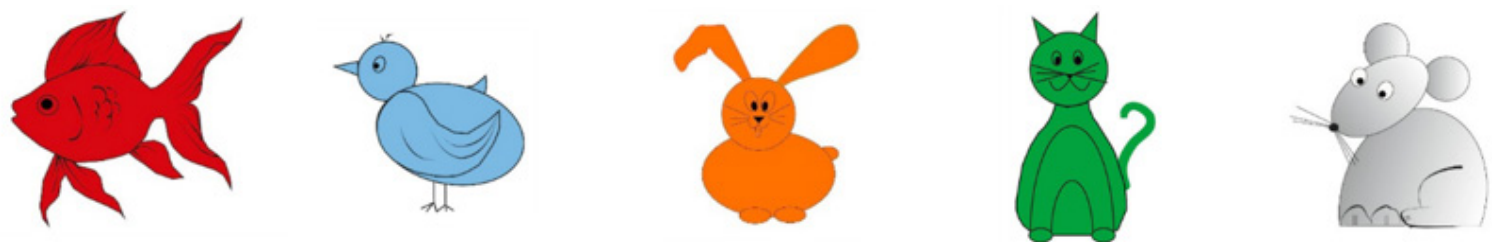

2. ábra: A képfelismerő játék képernyőképe

Szám-és betüfelismerés feladat

Az első mérési alkalmat a szám- és betűfelismerés, valamint a betű- és számkereső játék alkotja. A szám- és betűfelismerés feladatban a gyermeknek a megjelenő számok, betűk közül arra kell kattintania, amit a Kismackó mond. A két feladat minden korcsoportban azonos: 15 feladatelemből (item) áll, melyek fokozatosan nehezednek. Az első öt számfeladatnál 5-5 kártya közül kell kiválasztani az elhangzott számot, a következő tíz feladatnál pedig 7-7 kártyát lát egyszerre a gyermek. A számfelismerés feladatelemek nehezedése során a számjegyek is bővülnek az egy számjegyűtől a négy számjegyüig. A betűfelismerés kártyákon az első feladatoknál nyomtatott nagybetűk, majd később kisbetűk, végül vegyesen nagy és kisbetűk is szerepelnek. Az első 11 feladatnál öt betűkártya látható egyszerre, majd hét. A feladatelemek fokozatos nehezedésének további jellemzője, hogy a kezdeti feladatelemeknél gyakoribb, ismertebb betűk szerepelnek, a későbbi kártyákon pedig megjelennek a kevésbé gyakori betűk is. A feladatok adaptivitását az biztosítja, hogy mind a szám-, mind a betűismeret esetében a gyermek egymást követő 
Focus teszt: új, számítógép-alapú vizsgálati eszköz 3-8 éves gyermekek számára

két tévesztése után a teszt nem ad további feladatelemeket. Azaz, a számokat, betűket még kevésbé ismerő gyermek esetében rövidebb a teszt, ők csak a könnyebb feladatelemekkel találkoznak. Ennek köszönhetően csökken a méréséhez szükséges idő, valamint sokkal kisebb mértékű az esetleges sikertelen válaszból adódó frusztráció is. A próbamérések tapasztalatai szerint a 3-8 éveseknek mind a szám-, mind a betűfelismerés esetében a sikeres feladatmegoldáshoz 90 másodperc elegendő.

\section{Elsajátitási motiváció}

Az elsajátítási motivációt a szám- és betűkereső játékok vizsgálják. Ezek a feladatok egyrészt a közepes kihívást jelentő feladatokon való kitartást, másrészt a feladatmegoldás pontosságát mérik. A feladat egy próbajátékkal indul, ahol a bal felső sarokban lévő ún. célkártyával azonos kártyákat kell megkeresni a kijelzőn látható nyolc kártya közül (3. ábra).
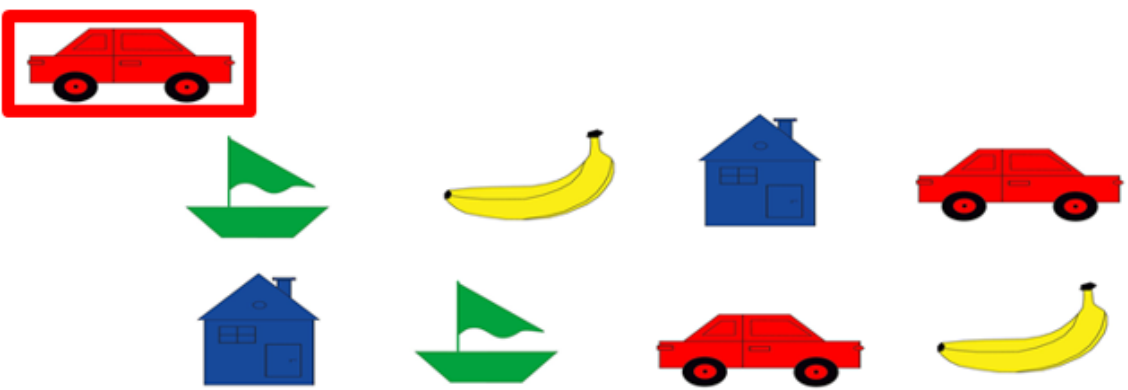

3. ábra: A szám- és betűkereső játékok próbafeladata

A próbafeladatot követően a játékban a hézségi szintje a nyolc egyre nehezedő szintgyermeknek meg kell keresnie az összes olyan számot/betüt, amit a célkártya mutat. Mind a szám-, mind a betűkereső játéknak nyolc, fokozatosan nehezedő szintje van, ezek közül a gyermek az életkora alapján 4-4 keresési feladatot old meg. A 4. ábra egy képernyőképet ből. Ezt a kereső feladatot a 4-5 éveseknek közepesen nehéznek, a 7 év felettiek esetében pedig könnyünek tekintettük. A szám- és betűkereső feladatot - a sorrendi hatás kiküszöbölése érdekében - a program felváltva adja mutat, ami a számkereső játék negyedik ne-

a gyermekeknek.

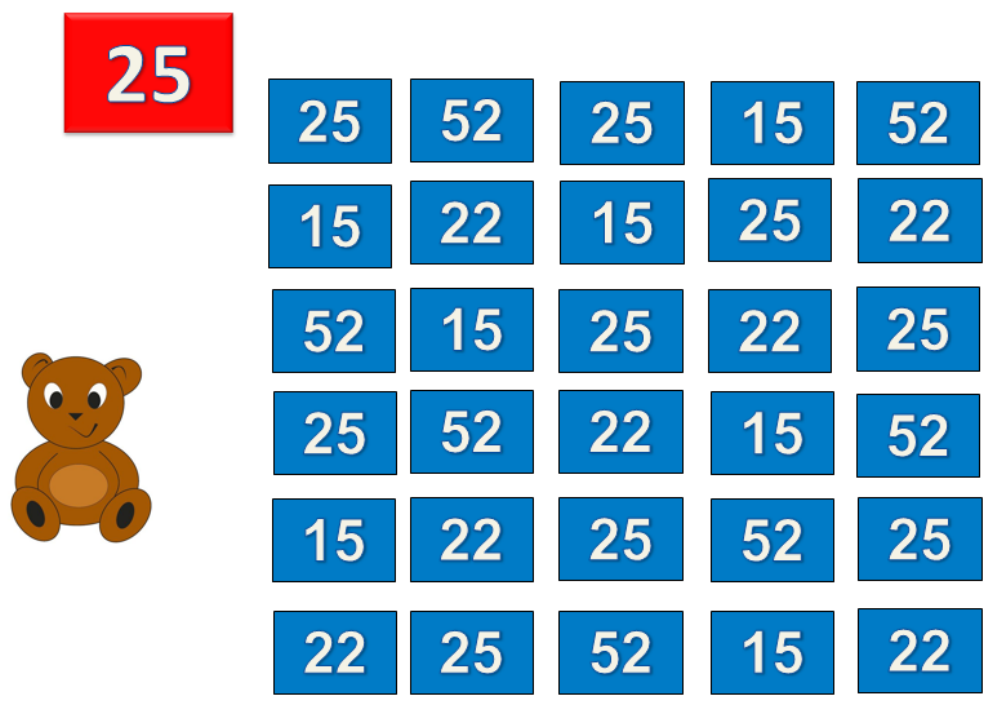

4. ábra: A számkereső játék mintafeladatának képernyőképe 
Józsa Krisztián - Barrett C. Karen - Józsa Gabriella - Morgan A. George

Végrehajtó funkció

A program második mérési alkalma a végrehajtó funkció feladatait tartalmazza. A vizsgálatot két feladattal végezzük, egy memóriajátékkal és a Zelazo (2006) által részletesen ismertetett $D i$ menzióváltókártyaszortírozóteszt(Dimensional Change Card Sort Test; DCCS) alapján készített feladattal. A kétféle feladatot - a sorrendi hatás kiküszöbölése érdekében -a program felváltva adja a gyermekeknek. Azaz, véletlenszerü elrendezésben a gyermekek fele a memóriajátékot, másik fele pedig a kártyaszortírozó játékot kapja először. Mindkét feladattípusnak nyolc nehézségi szintjét dolgoztuk ki - ezzel fedjük le a 3-8 éves életkori tartományt -, ebből 3-3 játékot kap minden gyermek életkora alapján, mely könnyü, közepesen nehéz és nehéz sorrendben követik egymást.

A memóriajátékban a hagyományos memóriajátéknak megfelelően téglalap alakú kártyákon különböző figurapárok vannak lefordítva elhelyezve a képernyőn. Amint a gyermek rákattint egy kártyára (vagy az érintőképernyőn megérinti), az megfordul, majd 2 másodperc múlva visszafordul. A játék 1-5. szintjén, amikor a gyermek megtalál egy párt, akkor az eltünik, ahogyan azt legtöbb esetben játszani szokták. A 6-8. szinten a megtalált párok nem tünnek el, csak visszafordulnak. Ez így nehezebb játék a hagyományos memóriajátékhoz képest. Ezen a szinten valószínúleg addig próbálkozik a gyermek a párok keresésével, amíg a saját belátása szerint megtalálta az összes párt. Ha az összes párt megtalálta, akkor tűnnek csak el a kártyák a képernyőről. Az 5. ábra egy képernyőképet mutat a memóriajátékból, ami az ötödik nehézségi szint. Ezt a szintet nehéz feladatként kapják a 4-5 évesek, de közepesen nehézként a 6-7 évesek.

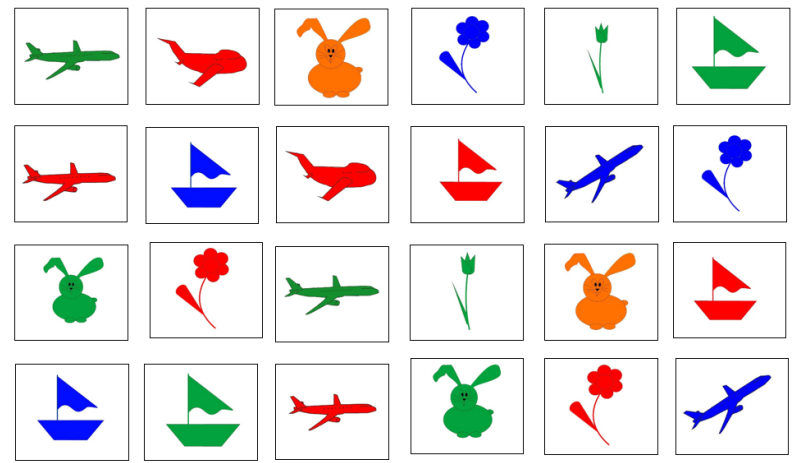

5. ábra: A memóriajáték mintafeladatának képernyőképe

A kártyaszortírozó feladatban a képernyőn elején egy gyakorlófeladat segíti a gyermeket megjelenő rajzokat szín vagy méret vagy alak a feladat jobb megértésében, ahol folyamatos szerint kell a megfelelő kosárba húzni. A 6. visszajelzést kap arról, hogy jól vagy helyteleábra a képernyő általános elrendezését mutatja. A kosarakra helyezett képekhez viszonyítva történik a középen lent megjelenő rajzok szortírozása valamelyik kosárba. A játék nül válogatta-e szét a figurákat. A próbafeladat után már nem kap visszajelzést a gyermek, hogy jól vagy rosszul oldotta-e meg a feladatot.
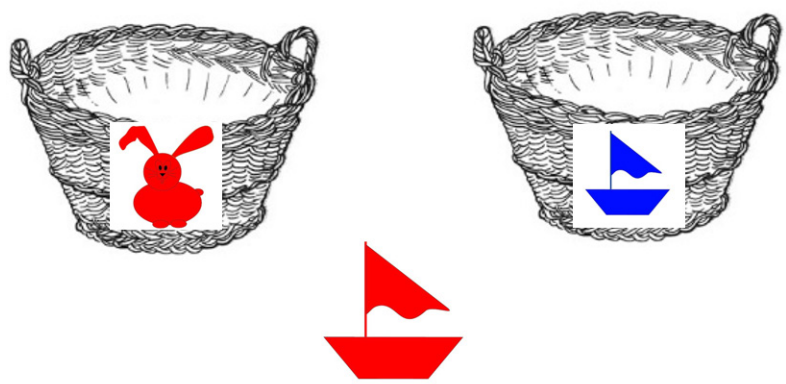

6. ábra: A kártyaszortírozó feladat képernyőképe 
Focus teszt: új, számítógép-alapú vizsgálati eszköz 3-8 éves gyermekek számára

Lássunk egy példát, a formajátékot. Amikor a gyermek formajátékot játszik, akkor a nyulat a nyúllal jelölt kosárba kell húznia, a hajót pedig a hajóval jelölt kosárba. A nehézséget a gyermek számára az jelenti, hogy figyelmen kívül kell hagynia a rajzok színét és méretét. Színjátéknál a piros nyúllal jelölt kosárba kell húzni minden olyan rajzot, ami piros, míg a kék színű rajzokat a kék hajóval jelzett kosárba kell tenni. Ebben a játékban figyelmen kívül kell hagyni a gyermeknek a rajz alakját és méretét. A kártyaszortírozó feladat 7-8. szintjén már négy kosár jelenik meg a képernyőn. Az utasítás ekkor nem mondja el a szétválogatás szabályát, hanem példát mutat, és ez alapján a gyermeknek kell kitalálnia a szabályt és aszerint rendezni a megjelenő figurákat.

\section{A FOCUS mérésböl képzett pontszámok}

Ebben a részben azzal foglalkozunk, hogy miként lehet számszerüsített, ezáltal elemezhető adatokat képezni a FOCUS teszttel végzett mérésekből. A szoftver egy adatbázisba menti a gyermek összes válaszreakcióját és az egyes válaszok (kattintások/képernyőérintések) között eltelt időt. Ebből az adatbázisból minden gyermek esetében többféle pontszámot származtattunk. Az alábbiakban ezeknek a képzett változóknak a létrehozását mutatjuk be röviden.

A szám- és betűismeret feladat esetében egy-egy indexet képez a szoftver arra, hogy a 15 feladatelemnek hány \%-át válaszolta meg helyesen a gyermek. Emellett az itemek ennél a két szubtesztnél egyesével is elemezhetőek.

Emlékezzünk rá, hogy a szám- és betűkereső feladatoknak egy könnyü, két közepesen nehéz és egy nehéz szintje van a gyermek életkora alapján, ehhez kapcsolódóan a következő pontokat számoljuk:

1. A szoftver rögzíti a célkártya megtalálásával eltöltött időt. Ez minden gyermeknél a két feladat esetében 2x4 másodpercben kifejezett idő. A feladattal eltöltött idő egy közelítő becslése a gyermek feladatokkal szembeni kitartásának, magába foglalja mind a helyes válaszokat, mind a hibákat, mint pl. a nem megfelelő kártyák érintését. Ez az idő azonban magába foglalja azt is, amikor a gyermek nem a feladattal foglalkozott, pl. nézelődött a teremben, ugyanis a számítógépes program nem képes észlelni az ilyenfajta viselkedést. A Megfigyelö értékelése cím alatt ehhez a kérdéshez még visszatérünk.

2. A megtalált kártyák százalékos aránya. A számítógép minden gyermeknek minden feladatban számol egy százalékos pontszámot a lehetséges jó kártyákból, amikhez hozzáért. A helyesen kiválasztott kártyák százalékos arányát a négy közepes kihívást jelentő feladatból összesítjük (két-két közepesen nehéz szám- és betűkereső).

3. Hibásan megérintett kártyák százalékos aránya. A számítógép itt is számol egy százalékos arányt minden gyermek minden feladatánál a rossz vagy a célkártyával nem megegyező megérintett kártyákból. A megérintett hibás kártyák százalékos arányát a négy közepes kihívást jelentő feladatból összesítjük.

4. Hibátlanság. A gyermekek teljesítményét akkor tekintjük hibátlannak egy adott szinten, ha az összes célkártyát megtalálta és nem ért hozzá egyetlen más, nem megfelelő kártyához sem. Ez tehát egy 0 vagy 1 értékű változó.

5. Keresési sikeresség. Mindkét keresőfeladat mind a négy nehézségi szintjéhez számolunk egy összesített változót: a megtalált kártyák százalékos arányához hozzáadunk százat és kivonjuk a hibásan érintett kártyák százalékos arányát, ezt az értéket elosztjuk kettővel.

A végrehajtó funkció feladatai esetében a memóriajátékokból és a kártyaszortírozó feladatokból számítunk összpontszámot. A kártyaszortírozó feladatok esetében a könnyü, a közepesen nehéz és a nehéz szint esetében is meghatározzuk a helyesen szortírozott kártyák \%-os arányát. A három nehézségi szint összevont átlaga a végrehajtó funkció indexe \%pontban kifejezve (Barrett, Józsa, Morgan E Gibbons, 2019; Józsa, Barrett \& Morgan, 2018).

\section{A megfigyelö értékelése}

A számítógépes adatok és pontszámok mellett a vizsgálatot végző személy is értékelte a gyermekek kitartását és érzelmeit a feladatvégzés 
közben. Ehhez egy táblázat formátumú értékelő lapot készítettünk (Józsa, Barrett, Józsa, Kis $\mathcal{E}$ Morgan, 2017). A következő szempontok mentén értékelték a gyermekeket.

1. Az adott feladat esetében melyik volt a legintenzívebb érzelem? pozitív, semleges, negatív

2. Az érzelem erőssége milyen volt a feladatvégzés közben?

- ha az érzelem közömbös volt, akkor az érzelmi intenzitás 0

- pozitív érzelem: 1 - enyhén pozitív (pl. zárt szájjal mosolyog;) 2 - közepesen pozitív (pl. nyitott szájjal mosolyog); 3 - erősen pozitív (pl. örömének hangot is ad a mosoly/nevetés mellett, pl. tapsol).

- negatív érzelem: 1 - enyhén negatív (pl. kicsit ráncolja a szemöldökét); 2 - közepesen negatív (pl. mérges vagy szomorú az arca); 3 - nagyon negatív (pl. a mérges és szomorú arc mellett hangot is ad hozzá vagy sír).

3. A kitartást úgy értékelték, hogy az idő hány százalékában összpontosított a gyermek a feladat megoldására: $1=$ $0-19 \%, 2=20-39 \%, 3=40-59 \%, 4=$ $60-79 \%, 5=80-100 \%$.

\section{A FOCUS teszt próbamérése}

A számítógép-alapú teszt első próbamérésében 274 fö 3-7 év közötti óvodás és általános iskolás vett részt. Az adatfelvételt egyetemi hallgatók végezték. A mérések egyénileg egy erre alkalmas külön szobában történtek az óvodákban és az iskolákban. Az adatfelvétel első és második mérési alkalma is nagyjából 10-20 percet vett igénybe két külön napon. A mérésvezető a gyermek feladatmegoldása közben megfigyelte és az értékelő lapon rögzítette a gyermek kitartását és érzelmi állapotát, míg a pedagógus kitöltötte az Elsajátítási motiváció (DMQ) kérdőívet (Morgan et al., 2019) a mérésben résztvevő gyermekekről.

A FOCUS teszt feladatai, szubtesztjei megfelelő differenciáló erővel bírnak, pszichometriai mutatói jók. Az itemek belső konzisztenciját mutató reliabilitások megfelelőek. A validitást a kérdőívből nyert ada- tokkal, valamint a megfigyelők értékeléseivel mutatott korrelációk támasztják alá, ezeket az adatokat Józsa, Barrett, Józsa, Kis és Morgan (2017), Józsa, Barrett és Morgan (2018), Barrett, Józsa, Morgan és Gibbons (2019) elemzései közlik.

Ahogy korábban már írtuk, a gyermek életkora alapján a program tartalmaz könynyű, közepesen nehéz és nehéz feladatokat. Azonban a leíró statisztikák adatai azt mutatták, hogy az életkor alapján közepes kihívást jelentő feladatok a gyermekek egy része számára könnyűnek bizonyult. Az életkor alapján közepes kihívásúnak vélt feladatok pedig a gyermekek egy része számára nehéz volt. A könnyűnek tételezett feladatok között is volt olyan, ami néhány gyermek számára nehéz volt. Az azonos életkorú gyermekek között is jelentősek az egyéni különbségek a tesztfeladatok megoldásának a sikerességében. Ezért - hasonlóan Morgan, Busch-Rossnagel, Maslin-Cole és Harmon (1992), valamint Wang, Liao és Morgan (2017) munkájához empirikusan határoztuk meg az egyes gyermekekre vonatkozó nehézségi szinteket, amelyeket ténylegesen könnyűnek, közepesen nehéznek és ténylegesen nehéznek bizonyultak. Az egyes gyermek számára a próbamérés alapján a következő empirikus nehézségi kritériumokat állítottuk fel:

a) Közepesen nehéz feladatok: a gyermek keresési sikeresség pontszáma (a) 50\%-90\% között van, vagy (b) meghaladta a 90\%-ot, és a feladatra fordított idő hosszabb volt, mint az átlagidő plusz az idő szórása.

b) Nehéz feladatok: ha a gyermek keresési sikeresség pontszáma 50-nél kevesebb.

c) Könnyü feladat: ha a gyermek keresési sikeresség pontszáma 90-nél több és a megoldáshoz kevesebb időt vett igénybe, mint a közepesen nehéz feladatnál megadott idő.

Az empirikusan definiált nehézségi szintek felhasználásával lehetséges meghatározni, hogy a gyermek fejlettségi szintjéhez viszonyítva melyik feladat, játék tekinthető közepesen nehéznek, optimális kihívó erővel bírónak. Az ezeken a feladatokon mutatott kitartás a jelzője az elsajátítási motivációnak. 
Focus teszt: új, számítógép-alapú vizsgálati eszköz 3-8 éves gyermekek számára

\section{Összegzés}

Az okostelefonok, tabletek, számítógépek ma már az óvodás gyermekek mindennapjaihoz is hozzátartoznak. Hódi, Tóth, B. Németh és Fáyné (2019) vizsgálata szerint a magyar óvodások több mint 80\%-a használ rendszeresen valamilyen informatikai eszközt. Ez az arány a fejlettebb országokban még magasabb. Az érintőképernyős és a nem érintőképernyős eszközöket is használják az óvodások, de az előbbit több gyermek. A digitális eszközök az óvodai képességfejlesztésben is megjelentek. Számos mobil applikáció érhető ma már el az óvodások játékos készségfejlesztésére. Például, Farkas és Berecz (2019) tanulmánya áttekintést ad az óvodai matematikai készségek fejlesztéséhez kapcsolódó applikációkról. Szabó (2018a, 2018b) a zenei készségek fejlesztéshez kapcsolódó alkalmazásokat mutat be.

A digitális fejlődés a pedagógiai diagnosztika eszközeit is megújította (lásd például Molnár és Csapó, 2019). A kognitív és az affektív szféra területén egyaránt új vizsgálati módszerek jelennek meg (Csapó és Zsolnai, 2015). A hagyományos tesztelés mellett fokozatosan megjelennek azok a technikák, melyek kisebb-nagyobb mértékben a számítógépes alkalmazásokra építenek. Ezek egy része a hagyományos vizsgálati eljárásokat ülteti át számítógépes környezetbe. Emellett fokozatosan egyre nagyobb teret kapnak azok a vizsgálati módszerek is, melyeknek nincs korábbi megfelelője, melyek informatikai háttér nélkül nem valósulhatnának meg (Józsa, Szenczi E Hricsovinyi, 2011).

Tanulmányunkban egy új, számítógép-alapú mérőeszközt mutattunk be. A FOCUS nevü teszt 3-8 éves életkorban teszi lehetővé az ATL bizonyos komponenseinek a mérését: betü- és számismeret, elsajátítási motiváció, és végrehajtó funkció. A mérőeszköz magyar-amerikai együttműködésben jött létre. A feladatokat úgy fejlesztettük ki, hogy azok mindkét kultúrához jól illeszkedjenek. Az előzetes eredmények arra utalnak, hogy a kifejlesztett mérőeszköz feladatai jó reliabilitással és validitással bírnak.

A szoftver első verzióját webalapú változatban készítettük el. A próbamérések során több alkalommal nehézségekben ütköztünk az online használat során. Az óvodák, iskolák wifi lefedettsége nem biztosította minden esetben a stabil internethasználatot. Ezért elkészítettük a programot mobilapplikáció formájában. A jelenleg elérhető magyar és angol nyelvű változat mellett elkészült a héber adaptáció. Folyamatban van a spanyol és szuahéli változat elkészítése (Amukune, Szabó \& Józsa, 2019), a közeljövőben tervezzük a kínai változat elkészítését.

A FOCUS teszttel széleskörü adatfelvételt kezdtünk meg a Kaposvár Vizsgálat keretében. Az óvodából az iskolába átívelő kutatásban több mint 600 gyermek vesz részt. A mintát az egyidejűleg iskolába lépő összes gyermek alkotja, azaz teljes városi lefedés valósul meg. E longitudinális kutatásban többek között azt vizsgáljuk, hogy a hazai társadalmi és oktatási környezetben milyen előrejelző ereje van az ATL összetevőinek (Józsa, Csima, Nyitrai és Podráczky, 2019).

\section{Köszönetnyilvánítás}

A kutatást az NKFI K124839 pályázat támogatja. A tanulmány elkészítése során Józsa Krisztián Bolyai János Kutatási Ösztöndíjban részesült.

\section{Felhasznált irodalom}

Amukune, S., Szabó, N. \& Józsa, K. (2019): The Adaptation process of an educational measurement: Creating the Kenyan version of FOCUS. In: Varga Aranka, Andl Helga és Molnár-Kovács Zsófia (szerk.): „Neveléstudomány - horizontok és dialógusok" XIX. Országos Neveléstudományi Konferencia. Absztraktkötet. MTA Pedagógiai Tudományos Bizottság PTE BTK Neveléstudományi Intézet, Pécs, 346.

Barrett, K. C. \& Morgan, G. A. (2018): Mastery motivation: Retrospect, present, and future directions. In: A. Elliot (Ed.), Advances in Motivation Science. Vol. 5., Elsevier, Amsterdam, 2-39.

Barrett, K. C., Józsa, K. \& Morgan, G. A. (2017): New computer-based mastery motivation and executive function tasks for school readiness 
and school success in 3 to 8 year-old children. Hungarian Educational Research Journal, 7.2. sz., 86-105.

Barrett, K. C., Józsa, K., Morgan, G. A. \& Gibbons, A. (2019, March): Children's mastery motivation and executive functions on the new FOCUS app. Presented at a symposium on Social, Emotional, And Self-Regulatory Influences on Children's Mastery Strivings, from Different Countries and Perspectives. 2019 SRCD Biennial Meeting March 21-23, 2019, Baltimore, Maryland, USA.

Blair, C. (2002): School readiness: Integrating cognition and emotion in a neurobiological conceptualization of child functioning at school entry. American Psychologist, 57. 2. sz., 111-127.

Blair, C. \& Diamond, A. (2008): Biological processes in prevention and intervention: Promotion of self-regulation and the prevention of early school failure. Development and Psychopathology, 20. 3. sz., 899-911.

Blair, C. \& Razza, R. P. (2007): Relating effortful control, executive function, and false belief understanding to emerging math and literacy ability in kindergarten. Child Development, 78. 2. sz., 647-680.

Burchinal, M., Magnuson, K., Powell, D. \& Hong, S. S. (2015): Early childcare and education. In: R. Lerner, M. Bornstein \& T. Leventhal (Eds.), Handbook of child psychology and developmental science. Volume 4. Ecological settings and processes, Chapter 6, Wiley, Hoboken, NJ, 1-45.

Bustamante, A. S., White, L. J. \& Greenfield, D. B. (2017): Approaches to learning and school readiness in Head Start: Applications to preschool science. Learning and Individual Differences, 56, 112-118.

Csapó Benő és Zsolnai Anikó (2015, szerk.): Online diagnosztikus mérések az iskola kezdó szakaszában. Oktatáskutató és Fejlesztő Intézet, Budapest.

Diamond, A. (2013): Executive function. Annual Review of Psychology, 64., 135-168.

D. Molnár Éva (2017): Erőfeszítés alapú kontroll és végrehajtó funkciók az önszabályozásban. Magyar Pszichológiai Szemle, 72. 4. sz., 533-547.

Farkas Krisztina és Berecz Antónia (2019): Hogyan játszhatnak matematikát az óvodások okostelefonon? In: Conference:
XXV. Multimedia in Education Conferences.

Ericsson Magyarország R\&D, Budapest. 144-150

https://doi.org/10.26801/MMO.2019.1.025

Garon, N. (2016): A Review of hot executive functions in preschoolers. Journal of SelfRegulation and Regulation, 2., 56-81.

Gilmore, L., Cuskelly, M. \& Purdie, N. (2003): Mastery motivation: Stability and predictive validity from ages two to eight. Early Education and Development, 14., 413-424.

Gliner, J. A., Morgan, G. A. \& Leech, N. L. (2017): Research Methods in Applied Settings: An integrated approach to design and analysis (3rd ed.): Routledge/Taylor \& Francis, New York, NY.

Hódi Ágnes, B. Tóth Edit, Németh Mária és Fáyné Dombi Alice (2019): Óvodások IKT-használata otthon - szülői minta és szerepvállalás. Neveléstudomány: Oktatás Kutatás - Innováció. 7. 2. sz., 22-41. https://doi.org/10.21549/NTNY.26.2019.2.2

Hyson, M. (2008): Enthusiastic and engaged learners: Approaches to learning in the early childhood classroom. New York: Teachers College Press; Washington, DC: National Association for the Education of Young Children.

Janeiro, I. N., Duarte, A. M., Araújo, A. M. \& Gomes, A. I. (2017): Time perspective, approaches to learning, and academic achievement in secondary student. Learning and Individual Differentes, 55., 61-68.

Józsa Gabriella és Józsa Krisztián (2017): Az affektív tényezők szerepe a végrehajtó funkcióban: A „meleg” végrehajtó funkció. Magyar Pszichológiai Szemle, 72. 4. sz., 559-577.

Józsa Gabriella és Józsa Krisztián (2018): Végrehajtó funkció: elméleti megközelítések és vizsgálati módszerek. Magyar Pedagógia, 118. 2. sz, 175-200.

Józsa Krisztián (2007): Az elsajátitási motiváció. Müszaki Kiadó, Budapest.

Józsa Krisztián (2016): Kihívások és lehetőségek az óvodai fejlesztésben. Iskolakultúra, 26. 4. sz, 59-74.

Józsa Krisztián, Szenczi Beáta és Hricsovinyi Julianna (2011): A tanulási motiváció számítógépalapú mérési lehetőségei. In: Csapó, Benő és Zsolnai, Anikó (szerk.) Kognitív és affektiv fejlödési folyamatok diagnosztikus értékelésének lehetöségei az iskola kezdő szakaszában. Nemzeti Tankönyvkiadó, Budapest, 147-171. 
Focus teszt: új, számítógép-alapú vizsgálati eszköz 3-8 éves gyermekek számára

Józsa, K., Barrett, K. C. \& Morgan, G. A. (2017): Game-like tablet assessment of approaches to learning: Assessing mastery motivation and executive functions. Electronic Journal of Research in Educational Psychology, 15. 3. sz., 665-695.

Józsa, K., Barrett, K. C., Józsa, G., Kis, N. \& Morgan, G. A. (2017): Computer-tablet mastery motivation tasks for 4-8 year-olds. Hungarian Educational Research Journal, 7. 2. sz., 106-126.

Józsa, K. \& Barrett, K. C. (2018): Affective and Social Mastery Motivation in Preschool as Predictors of Early School Success: A Longitudinal Study. Early Childhood Research Quarterly, 45. 4. sz., 81-92.

Józsa, K., Barrett, K. C. \& Morgan, G. A. (2018, July): Mastery motivation, executive functions, and preacademic skills in 3-7 year old Hungarian children using the FOCUS tablet app. (Symposium paper): In: ISSBD (szerk.) Conference handbook. 25th Biennial Meeting of the International Society for the Study of Behavioural Development, ISSBD, July 15-19, 2018 Gold Coast, Australia. 39. URL: https://www.issbd2018.org/

Józsa Krisztián, Csima Melinda, Nyitrai Ágnes és Podráczky Judit (2019): A korai fejlettségi mutatók szerepe az iskolai sikerességben: egy longitudinális kutatás első lépései. In: Juhász Erika és Endrődy Orsolya (szerk.), Oktatás Gazdaság - Társadalom. HERA Évkönyvek VI. Magyar Nevelés- és Oktatáskutatók Egyesülete, Budapest, 848-860.

McClelland, M. M., Acock, A. C. \& Morrison, F. J. (2006): The impact of kindergarten learningrelated skills on academic trajectories at the end of elementary school. Early Childhood Research Quarterly, 21. 4. sz., 471-490.

McClelland, M. M., Cameron, C. E., Connor, C. M., Farris, C. L., Jewkes, A. M. \& Morrison, F. J. (2007): Links between behavioral regulation and preschoolers' literacy, vocabulary, and math skills. Developmental Psychology, 43. 4. sz., 947-959.

Mercader, J., Presentación, M-J., Siegenthaler, R., Moliner, V. \& Miranda, A. (2017): Motivation and mathematics performance: a longitudinal study in early educational stages. Revista de Psicodidáctica, 22. 2. sz., 1-14.

https://doi.org/10.1387/RevPsicodidact.16466

Milner, B. (1963): Effects of different brain lesions on card sorting. Archives of Neurology, 9. 1. sz., 90-100.
Mischel, W., Shoda, Y. \& Rodriguez, M. L. (1989): Delay of gratification in children. Science, 244, 933-938.

Molnár Gyöngyvér és Csapó Benő (2019): A diagnosztikus mérési rendszer technológiai keretei: az eDia online platform. Iskolakultúra, 29. 4-5. sz., 16-32.

https://doi.org/10.14232/ISKKULT.2019.4-5.16

Morgan, G. A., Busch-Rossnagel, N. A., MaslinCole, C. A. \& Harmon, R. J. (1992): Individualized assessment of mastery motivation: manual for 15 to 36 month old children. Colorado State University, Fort Collins.

URL: https://sites.google.com/a/rams. colostate.edu/georgemorgan/masterymotivation

Morgan, G. A., Harmon, R. J. \& Maslin-Cole, C. A. (1990): Mastery motivation: Definition and measurement. Early Education and Development, 1, 318-339.

Morgan, G. A., Józsa, K. \& Liao, H.-F. (2017): Introduction to the HERJ special issue on mastery motivation: Measures and results across cultures and ages. Hungarian Educational Research Journal, 7, 2. sz., 5-14.

Morgan, G. A., Wang, J., Barrett, K. C., Liao, H.-F., Wang, P.-J., Huang, S.-Y. \& Jozsa, K. (2019): The Revised Dimensions of Mastery Questionnaire (DMQ 18): A Manual and Forms for Its Use and Scoring. Colorado State University, Fort Collins, CO.

URL: https://sites.google.com/a/rams. colostate.edu/georgemorgan/masterymotivation

Morgan, P. L., Farkas, G. \& Wu, Q. (2011): Kindergarten children's growth trajectrojies in reading and mathematics: Who falls incresingly behind? Journal of Learning Disabilities, 44. 5. sz., 472-488.

Nagy József (2000): A XXI. század és nevelés. Osiris Kiadó, Budapest.

Nagy József (2010): Új pedagógiai kultúra. Mozaik Kiadó, Szeged.

Nagy József, Józsa Krisztián, Vidákovich Tibor és Fazekasné Fenyvesi Margit (2004): DIFER Programcsomag: Diagnosztikus fejlödésvizsgáló és kritériumorientált fejlesztő rendszer 4-8 évesek számára. Mozaik Kiadó, Szeged.

National Education Goals Panel (NEGP) (1997): Getting a good start in school. National Education Goals Panel, Washington DC.

Normandeau, S. \& Guay, F. (1998): Preschool behavior and first-grade school achievement: 
The mediational role of cognitive self-control. Journal of Educational Psychology, 90., 111-121.

Peterson, E. \& Welsh, M. C. (2014): The development of hot and cool executive functions in childhood and adolescence: Are we getting warmer? In: Goldstein, S. \& Naglieri , J. A. (eds.), Handbook of executive functioning. Springer Science Business Media, New York, NY, 45-65.

Razza, R. A., Martin, A. \& Brooks-Gunn, J. (2015): Are Approaches to Learning in kindergarten associated with academic and social competence similarly? Child Youth Care Forum, 44. 6. sz., 757-776. https://doi.org/10.1007/s10566-015-9307-0

Snow, K. L. (2006): Measuring school readiness: Conceptual and practical considerations. Early Education and Development, 17.1. sz., 7-41. https://doi.org/10.1207/s15566935eed1701_2

Szabó Norbert (2018a): Zenesziget. Játékosítás (gamifikáció) digitális eszközökkel az ének-zene oktatásban. Gyermeknevelés, 6. 2. sz., 97-107. https://doi.org/10.31074/gyn2018297107

Szabó, N. (2018b): A cél szentesíti az (IKT-) eszközt a zeneoktatásban? Gyermeknevelés, 6. 2. sz., 132-138. https://doi.org/10.31074/gyn20182132138
Tsermentseli, S. \& Poland, S. (2016): Cool versus hot executive function: A new approach to executive function. Encephalos 53, 11-14.

Wang, P.-J., Liao, H.-F. \& Morgan, G. A. (2017): The Revised Individualized Structured Mastery

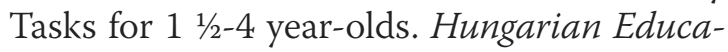
tional Research Journal, 7. 2. sz., 86-105. https://doi.org/10.14413/HERJ/7/2/6

Zelazo, P. D. (2006): The Dimensional Change Card Sort (DCCS): A method of assessing executive function in children. Nature Protocols, 1, 297-301.

Zelazo, P. D., Blair, C. B. \& Willoughby, M. T. (2016): Executive function: Implications for education (NCER 2017-2000) National Center for Education Research, Institute of Education Sciences, U.S. Department of Education, Washington, DC.

Zelazo, P. D. \& Müller, U. (2002): Executive function in typical and atypical development. In U. Goswami (Ed.), Handbook of childhood cognitive development. Blackwell, Oxford, 445-469..

Zelazo, P. D., Müller, U., Frye, D. \& Marcovitch, S. (2003): The development of executive function in early childhood. Monographs of the society for research in child development, 68. 3. sz., VII-137.

\section{FOCUS test: A new, computer-based assessment for 3-8-year-old children}

The paper describes the FOCUS (Finding Out Children's Unique Strengths) test, a new, computer-based assessment that measures mastery motivation and executive functions as well as alphabet and number recognition among 3-8-year-old children. Mastery motivation and executive functions are not only important components of approaches to learning (ATL), but also play a key role in success at school. The paper reviews the theoretical background of the FOCUS test, its structure and subtests. Results from pilot testing are also discussed. An initial face-to-face pilot study involved 12 preschool children. During the second pilot testing, the new, computer-based assessment was administered to 247 children aged 3-8 years. Reliability and validity were adequate. Besides the online version, an offline mobile application was also created. Both the web-based version and the mobile application are available in English and Hungarian. Finally, the paper briefly describes recent revisions of the test and its implications for future research.

Keywords: FOCUS, approaches to learning, mastery motivation, executive functions, computer-based assessment

Józsa Krisztián, Barrett C. Karen, Józsa Gabriella és Morgan A. George (2019): FOCUS teszt: új, számítógépalapú vizsgálati eszköz 3-8 éves gyermekek számára. Gyermeknevelés, 7. 2-3. sz., 111-124. 